Historic, Archive Document

Do not assume content reflects current scientific knowledge, policies, or practices. 


\section{Downs Standard Dahlias}

These are moderate priced varieties that we recommend highly-beautiful large flowered Dahlias that have proven their worth in gardens all over the country. The prices, though low, are forfirst-class tubers

of the very finest quality; guaranteed true to name.

Alice Whittier. A beautiful cactus Dahliá of clear light yellow. Very large in size, with the many blooms held on excellent stems over a tall and vigorous busin.

Ambassador. Salmon, amber and pink shadings around a center of soft yellow. This immense cactus Dahlia was sold for $\$ 50$ when first introduced, and has won innumerable prizes.

Bonnie Brae. An enormous Decorative, so large it's wiry stem can not hold it erect. The color of cream, with pink shadings.

Champagne. Chamois in a light golden shade, growing darker toward the center. This is a Decorative of good size, witn excellent bush habits and fine stems.

Earle Williams. Rich scarlet petals, tipped with white. Sometimes the blooms are all scarlet. Either way, this large Decorative is a beautiful fiower. See picture.

E1 Dorado. Of golden yellow, with amber shadings, this Decorative has attracted considerable attention at Dahlia shows. It keeps very well, has a fine stem, and is one of the best for commercial uses.

F. W. Fellows. This beauty oi orange-scarlet is larger than many a better known cactus. It's long, tightly twisted petals are incurved over a perfect center. See picture.

George Walters. Old gold, deep rose and salmon, blended.

Harry Sheldon, Jr. White, with an outside row of delicate shell pink petals. A dainty Decorative. on a vigorous bush of spreading habit. It flowers profusely.

Insulinde. Beautiful blooms of bronzy oldgold, held on top the stem umbrella fashion. A large Decorative, unique in shape, with the outer petals dropping not unlike an [ris. A good blooner, and worth several times

Islam Patrol. Scarlet and gold-golden tips on scarlet petals. With it's glorious coloring, great vigor and fine blooming qualities, this is one of our favorite hybrid-cactus Dahlias.

Jersey's Beacon. Chinese scarlet, with a paler reverse, giving a two-toned effect. A Decorative, almost globular in form, and of very good size

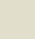

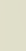

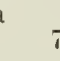

\section{西}

1

Jersey's Beauty. Being an excellent keeper and beautiful pink in color, this is the most popular cut-flower variety in many markets. A Decorative, with stem, bush and color to commend it.

Jersey's Gem. Another one of the famous "Jersey" group-a Decorative of delicate lavender pink that is extremely effective when arranged with white varieties.

Jersey's Jewel. Long petals of clear pink. A Decorative, large and with good habits; but not, with us, a prolific bloomer.

Judge Marean. A large beauty of salmon pink and golden yellow, beautifully blended. A prolific blooming variety, of the Decorative type, on stiff. wiry stems.

Kalif. A bright scarlet Dahlia of the hybridcactus type. The good-sized blooms are borne very freely. They keep well. have fine stems, and are excellent for commercial uses.

Mariposa. The incurved petals of this perfectly formed Hybrid-Cactus are of delicate pink, often flushed violet and giving the effect of lavender. Large flowers on straight, strong stems.

Mr. Alexander Waldie. In color similar to Bonnie Brae. It has a better stem than that variety, though it is not quite so large. A Decorative.

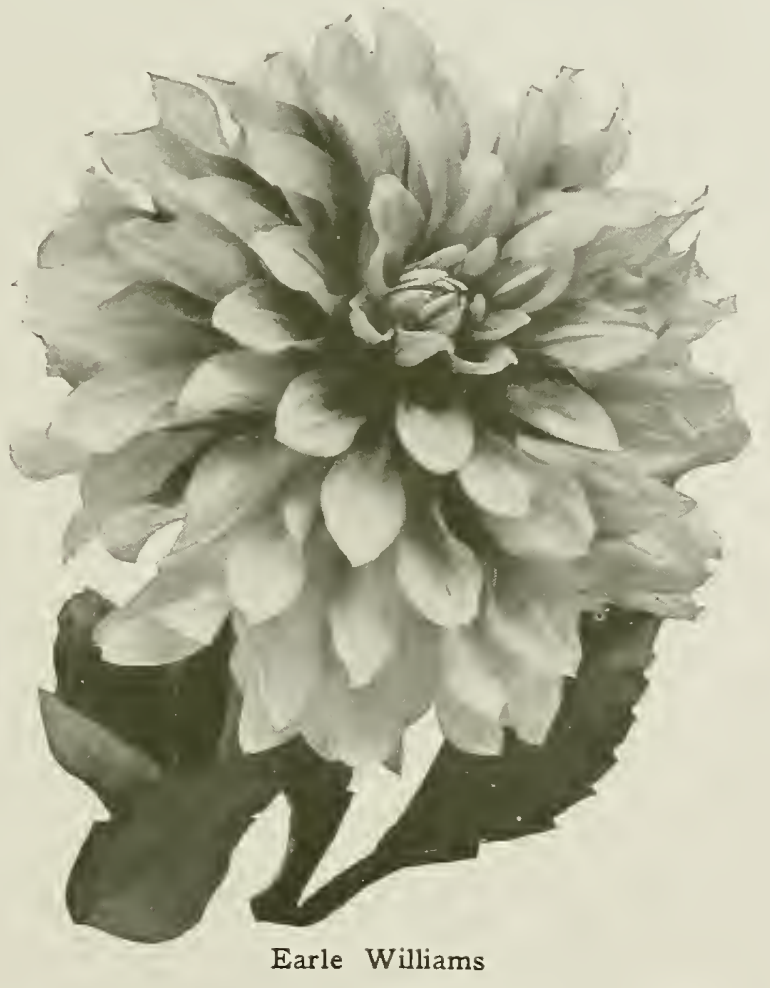

\section{DOWNS DAHLIA FARMS, Clayton, New Jersey}


Mrs. I deVer Warner. This clear lilac-rose Decorative is remarkable for its purity of color. The plant is vigorous and prolific, bearing many large, iong-keeping blooms on fine stems. Taken all around, this is one of the best Dahlias of moderate price.

Patrick O'Mara. Not a large Dahlia, but a mighty good one. Each plant bears an abundance of orange buff blooms that keep well when cut. Decorative.

Paul Michael. A big Decorative, almost the color of gold. Blooms of this variety often reach ten inches across them.

Robert Treat. Almost the color of the American Beauty rose. It bears abundantly large blooms that are held erect over a tall and vigorous plant. Decorative type.

Rollo Boy. Delicate amber, shading to old gold. The Hybrid-Cactus blooms are large, they keep well, and are held on the best of stems.

Rosa Nell. This is not a prolific varicty, but every bloom "rings the bell." Immense flowers of bright cerise, without tints or shadings of any kind. A deep, full Decorative, with fine stems. One of our favorites.

Shirley E. Shattuck. A Decorative of orchid lavender; fine stems hold the many tlowers over a bush of semi-dwarf habit.

Mrs. Carl Salbach. Soft rose pink blooms, flushing lavender-and many of them. This Decorative keeps very well when cut, and has long, stiff, straight stems that do not require disbudding. See picture.

Susan G. Tcvis. An extremely soft and pleasing shade of lilac, with a blucr undertone. Annther Decorative, and a good one.

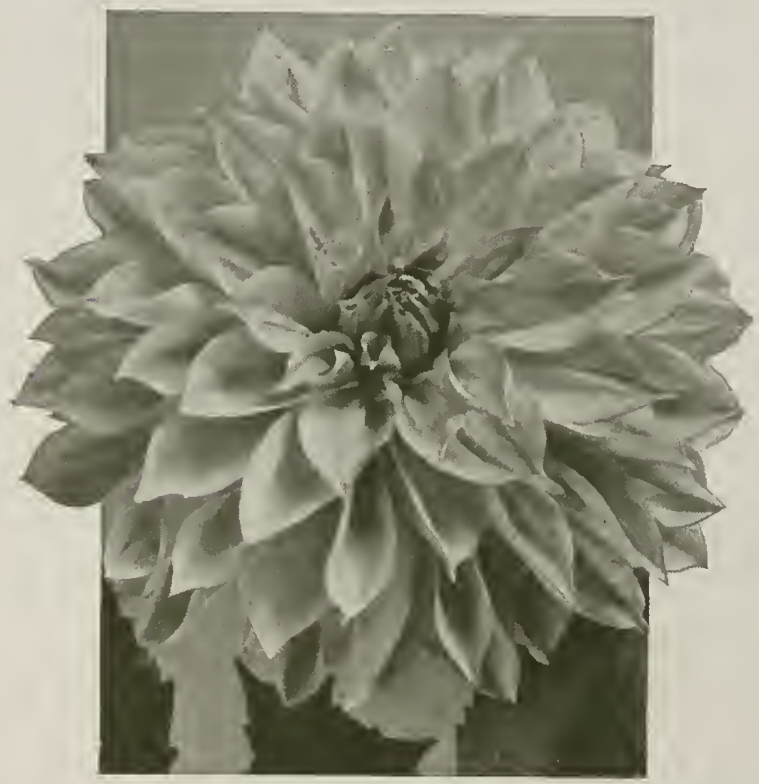

Mrs. Carl Salbach superior in lavenders. The large blooms are held erect on excellent stcms over a tall plant with lace-like foliage.

The Bandit. Narrow petals-that curl and twist-of mahogany-red and pure gold; a dazzling combination. The large Hybrid-Cactus blooms are held erect on black wire-like stems. It was awarded a Certificate by the A. D. S.

Trentonian. A coppery-bronze Decorative, held straight across the top of a canc-like stem. Petals are broad and flat, fcrming an attractive flower of good size that has won many a prize. Certificated by the D. S. of N. J.

The U. S. A. With a vivid orange coloring that has made it very popular. A large lower of the peony type, with fine stem.

Venus. A beautiful Decorative of creamywhite, often suffused with red or violet-rose. It blooms abundantly on extra fine stems, and is particularly valuable for floral work.

White Sister. A pure white Decorative of lovely formation.

Wizard of $\mathrm{Oz}$. Very large flowers of amber-pink, shaded with salmon. Decorative, with the blooms borne profusely on fine stems. An all-around, good Dahlia that will grace any garden. 